た. 患者白血球 histamine 遊離が平均以上を示した血清 5 例と平均以下であった血清 5 例の RPMC 感作能は平 均以上の者の RPMC 㤫作能は平均 $22 \%$ に対し, 平均以 下の者のそれは平均 5\%であった. 患者血清10例. 健常 人血清 4 例による感作 RPMC よりの histamine 遊離量 は，患者血清では平均 $16 \%$ ，健常人血清では平均 $2 \%$ 内 外であり明らかな差が認められた。また RPMC 感作能 と臨床症状, PK 反応闒值にお扎ては若干の相関傾向が 認めら机だ他の検査結果とは相関傾向は認められなか った.

まとめ：人白血球の代りに動物細胞使用の法が特異抗 原検索や reagin 検出の一つの方法として用いうるか否 が，現在の重要な研究課題である。今回われわれの試 みた人血清感作 RPMC 加らの抗原添加による histamine
遊碓を利用しての鼻アレルギ一患者血清の RPMC に対 する感作能の測定は少量の採血で実施でき，また血清の 冷温下での抗体価の安定性より反復実験が可能であり患 者血清で感作された RPMC からの histamine 遊䧹は平 均 $16 \%$ であるのに対し，正常人血清のそれは平均 $2 \%$ 内 外であり両者に充分な差が認められ，また若千の例数で はあるが白血球 histamine 遊離や臨床症状の程度，RK 反応間值等との間に認められた相関傾向は人血清RPMC 感作能の测定が in vitro の reagin 検出法の一つとし て充分期待出来るものと思われた。

質問 久松建一（日大）. 特異抗原添加時の R.P.M.C の数について，応答 馬場俊吉 (日本医大). 1) 使 用した RPMC 数は $1 \mathrm{ml}$ 中 $2.5 \times 10^{6}$ 個であった.

B 79-1128-94865

73. ヒスタミン担 $\mathrm{r}$ グロブリン (H-rgl) のラット肥 㭌細胞脱顆粒（RMCD）に及ぼす阻止効果

\author{
島田哲男・石川 哮・藤田洋右・結束信子（）
}

Parrotにより創製されたヒスタミン担 $\gamma$-gl (以下 Hrgl と略す) が，内科，小児科領城で，主として気管支 喘息に有効であるとする報告は多く，最近では皮膚科領 域で慢性尋麻診に, 1 回 3 vial, 週 2 回使用する大量療 法が有効であるとする報告むみられる。しかし，この作 用機序について, Parrot は「H-r.gl は $\gamma$-gl t carrier とし， histamine をhapten とする複合抗原で，投与を 受けた個体では，抗 histamine 抗体が壁生されることに よる」といら仮説を立ているが，抗 histamine 抗体は今 だ証明されていない

一方, Lichtenstein らは, in vitroにおける白血球 histamine 遊離の系に $10^{-7} \sim 10^{-6} \mathrm{M} の$ histamine を加 えることにより, histamine 遊離を50\%抑制することが できることを示し，生体内で遊離された histamine が, histamine 遊離を feed back している可能性を示唆し, basophilic leucocyte または mast cell には, histamine receptor があることを証明した，われわれはこの事実を ふまえた上，H-rgl の作用機序解明のため rat mast cell degranulation (RMCD と略す) を用い，次のような実
験を行なった。

方法：250 300g の Wister rat 腹腔内に histamine $0.15 \mu \mathrm{g}$, rat $\gamma \mathrm{gl} 12 \mathrm{mg}, \mathrm{HSA} 12 \mathrm{mg}$, rat $\mathrm{H}-\gamma \mathrm{gl} 12 \mathrm{mg}$ t Tris ACM buffer 10ml に溶き, またTris ACM buffer のみ $10 \mathrm{ml}$ 等を注入， 1 時間放置後断頭，腹腔内に c o mpound 48/80 $0.625 \mathrm{mg} / \mathrm{kg}$ をそれぞれに注入, 90秒後 に腹腔液を採取し, 900 回転, 10 分間遠沈後, 直ちに, $0.25 \%$ neutral red で染色し, 鏡検, 100個の mast cell 中の degranulation をおこしている mast cell の数を\% で表わし， 3 回くり返し平均值をもとめた。

結果: Tris ACM 使用群では, 約 70\%の degranulation を認め, これに対し, histamine, HSA 使用群で は, 何等 degranulation inhibition を認めず, $r$-gl 単独 使用群では，平均約 $57 \%$ でやや inhibition 䜅めた。 また $\mathrm{H}-r g 1$ 使用群では， degranulation の平均値は $40 \%$ であり, 統計学的にも, histamine 単独使用群と $\mathrm{P}<0.01$ で有意の阻止效果を認め，また $\gamma$-g1 侦用群とも $0.02<$ $\mathrm{P}<0.05$ で有意の阻止効果を認めた.

そこで，更に，向故 H-rgl が RMCDを抑制するが 
追試検討した。

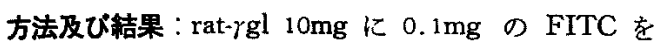
conjugate, Sephadex G 25 で free の FITC 除去し た後 $200 \mu \mathrm{g}$ in vitro で, rat 腹腔内 total cell $2 \times 10^{6}$ 個と incubate の後, wash, 螢光顕微鏡で観察した.こ の際, Staining の Specificity を確管するため，あらか じめ, unconjugated-rat-rgl $30 \mathrm{mg}$ および non specific protein として, HSA 30mg で pretreatmentを行なっ た.

HSA で pretreatment を行なった RMC の䖝光写真 では，RMC の全周，あるいは capping の形で，よくそ の surface に rat-rgl の存在が悲められたが, unconju-

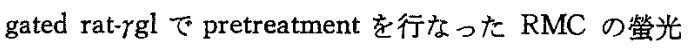
写真では complete inhibitionされた。

考案: 以上の結果から，H-rgl の作用機序について考 察すると, まず rgl が rat $の$ mast cell $の$ surface に 固着し,その結果, $r \mathrm{gl}$ が carry している histamine が, cell surfaceで high concentration の状態となり, そのため feed back mechanism により degranulation inhibition がおこると考えた。

しかし，問題点として，1。この実験では degranulation による検討のみで, histamine assay は行なってい ないので, degranulation をおこさなくても, histamine が細胞外に出ているかもしれないといら可能性．2. 本 実験は rat mast cell についての検討であって，人の mast cell, あるいは basophilic leucocyte について考え
る時, 人の mast cell は IgEを fix するとしても， IgG については今だ不明である. 3. rat mast ell に rat-rgl が fix することが証明されたが，これが molecule のど の部分で fix するのか.

等の検討が，今後に残された問題である.

質問 奥田 稔 (和医大). Masct cell にヒスタミン receptor があるのは他の実験でむ確められている，r-gl の代りに他の蛋白たとえば Albumin で代用できるので はないか. 応答 島田哲男 (千葉大). rat $の$ r $\mathrm{gl}$ が RMC に fix することは，すでに1969年に Johnson によって証明されている。 それで ratの rgl に histamineをつけたものを使用した。質問 佐く木好久（城 西歯大). スライドの cap formation はどういことな のか. 応答 島田哲男 (千㷛大). capping の意味 は形態的な意味から用いた。質問 浅井政二郎 (日 本医大). HSA を用いているが，この理由は？この の HSA 採取者の減感作末既を調べたか。 $r g l$ を用いて いるが, この理由は？ 応答 島田哲男 (千葉大).

histamine 担 $r g l$ の作用機序として, rat $r g l$ を使用 し, non specific な Protein としての作用を除く意味で HSA を使用した。応答 石川哮（千葉大），(1) rat-mast cell えの $\gamma$-gl fixation が specific であるとい う証明なので, nonspecific attachmentを利用しての脱 顆粒阻止であれば，それでよいと思う。(2)HSA は hetero の protein で non specific attachment を防ぐとい5

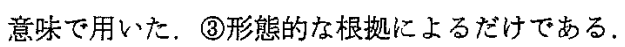

\section{4. 慢性炎症患者の血中ケイ素量について}

武藤二郎・島田孝之・小倉寿夫・依田 勝 - 中山杜人 - 金子 裕（群馬大）

耳䶊科領域における慢性化膿性炎症の原因的要素の一 つとして，ケイ秦が積極的に重要な役割を果しているこ とが, 疫学的, 組織学的に，また実験的に明らかにされ た（武藤他，1970，1973，1974）。慢性炎は，地域的に は新しい火山岩地帯に多く，また戦後徐々に減少しうつ あるといら疫学的傾向をもっているが，これと対照的な 変動を示すものがアレルギー疾患である，鼻アレルギー などは近年増加しつつあり，副鼻腔炎でも浮腫型の占め
る率が大きくなっている，そしてこのような変動はケイ 素の摄取量や組織内ケイ素濃度と密接な関連をむって行 われている，本研究では，慢性炎とアレルギーの患者の 血中ケイ素濃度を比較検討した。

まず，表のように，慢性中耳炎，慢性副鼻腔炎，鼻了 レルギー、鼻過敏症（鼻アレルギー様症状を示すむの） について，耳や鼻の所見と既往歴，家族歴をしらふる と，中耳炎や副鼻腔炎ではそれぞれ鼻や耳に感染性炎症 